\title{
The Judeo-Christian Concept of 'Sacrifice' and Interpretation of Human Sacrifice in Uganda
}

\author{
Paddy Musana \\ Department of Religion and Peace Studies, School of Liberal and Performing Arts, \\ College of Humanities and Social Sciences, Makerere University, Kampala, Uganda \\ E-mail address: musana@arts.mak.ac.ug
}

\begin{abstract}
There is today a marked increase of reports on human sacrifice especially in the media and police. Accounting for these actions have been difficult given the secrecy that surrounds it especially given the fact that it is considered a 'ritual' enacted for spiritual-magical benefits. The practice of human sacrifice has antecedents in most world religions, many times serving the ritual-magical purpose of setting and maintaining relationships with what humans in the respective belief systems consider as divine (supernatural). This paper seeks to investigate and relate the meaning of 'sacrifice' from the JudeoChristian faith in the Ugandan context, given the place and influence of Christianity in the Ugandan community. The conclusion of the evidence provided is that the new forms of sacrifice in Uganda today do not in any way conform to the Judeo-Christian form and understanding. In essence, the phenomenon confirms the fact that in spite of the spread of Christianity in the country, most of its adherents still conform to the indigenous beliefs and practices; as it (Christianity) serves as a veneer.
\end{abstract}

Keywords: Sacrifice; Christianity; Religion; Sacred

\section{INTRODUCTION}

\section{1. Sacrifice: Definition}

By sacrifice in the real sense is universally understood the offering of a sense-perceptible gift to the deity as an outward manifestation of our veneration for Him and with the object of attaining communion with Him. Strictly speaking however, this offering does not become a sacrifice until a real change has been effected in the visible gift (e.g. by slaying it, shedding its blood, burning it, or pouring it out $)^{1}$. When we talk of 'change', we mean either visible or invisible realities that happen as a consequence of what has been done. This makes sacrifices rituals. However, it is equally important to note that the English origin of the term 'sacrifice' is Latin where sacer infers 'holy' or 'sacred', and facer stands for 'to make'. This makes the conjoined term imply something made holy or through destruction is dedicated to the deity (divinity). The scientific significance of sacrifice lies in the fact that the material of the bloody sacrifices $^{2}$ is taken from things used as food and drink, and the best of these possessions. This

${ }^{1}$ Catholic Encyclopedia-http://www.newadvent.org/cathen/13309a.htm

${ }^{2}$ In most cases, sacrifice connotes slaughter and the shedding of blood. It is the symbolic significance of blood that bears much meaning as life is given (offered) to the deity to whom the sacrifice as a form of worship is directed. 
implies that the worshipper and the sacrifice victim should have a certain degree of associationthe gift should be of high value and associated with the physical well-being of the worshipper. This is why, as we shall discuss later, there are particular aspects to consider in the choice of a sacrifice like age, colour, health and physical appearance The bloody sacrifice in this case has a symbolic significance-the self-giving nature of the worshipper, who through the offered sacrifice receives acceptance or recognition from the deity. As Girard observes:

In the ritualistic societies most familiar to us-those of the Jews and of the Greeks of the classical age-the sacrificial victims are almost always animals. However, there are other societies in which human victims are substituted for the individuals who are threatened by violence. Even in the fifth century Greece-the Athens of the great tragedians-human sacrifice had not, it seems, completely disappeared. The practice was perpetuated in the form of pharmakos, maintained by the city at its expense and slaughtered at the appointed festivals as well as at a moment of civic disaster (Girard, Violence and the Sacred).

As Beattie ${ }^{3}$ notes, the element of exchange in the relationship between humans and spirits underpins the concept of sacrifice as a means of destruction of what is offered, like the immolation of a living creature. While there are situations where the victim is not killed, there are also other items that may be offered with no blood shedding. The idea of deprivation on the part of the sacrifice needs to be acknowledged in this case. As he notes,

It is especially plain in the case $\mathrm{f}$ sacrifice that there can be no adequate comprehension of what is going on in other cultures unless the ideas in the minds of the actors are understood. An anthropologist who is watching a sacrifice must ask not only 'what they are doing?' but also 'what they think they are doing?' And the meaning of sacrifice varies widely from culture to culture....So not all sacrifices are communions, though some are. But the notion that something is yielded up, given over to god or spirit, is universal. Where ghosts and spirits are regarded as separate and individual powers, dependent on men as men are dependent on them, the rule of do ut des may prevail, and a sacrifice may be thought of as a kind of bargain. But it is never simply this. Ghosts and gods are not people, and the symbolic aspect of sacrifice is intrinsic. Sacrifice is a symbolic act; trading in the market is not. If we regard sacrifice as the making of a gift to a spirit, we must ask just what it is that is given and received ${ }^{4}$.

As for defining sacrifice as ritual, this is another complex ground that needs coverage for us to decipher the meaning and significance of the 'dramatic' aspects of religious practice and experience. By linking sacrifice to rituals we underscore the power of language, signs and symbols in cultural practices and beliefs. This becomes complex in the African context where traditionally there is no dichotomy in perception of life: the world in one whole, not divided into sacred and religious. It is this holistic approach that confers complexity to our philosophy. It is here that our definitions do not have to be tied, for example, to the sociological or religious categories in our discussion of sacrifice as ritual ${ }^{5}$, but rather, as that aspect that inherently

\footnotetext{
${ }^{3}$ Other Cultures, pp.233-237

${ }^{4}$ Ibid

${ }^{5}$ Lotz would refer to it as 'those conscious and voluntary, repetitious and stylized symbolic bodily actions that are centred on cosmic and /or sacred presences...Even more fundamentally, ritual is intentional bodily
} 
defines relationship and being. It is concern of being that confers upon us the need to be in harmony, or at peace with ourselves and others (extending beyond persons to the metaphysical world). Theoretically, sacrifice then becomes 'gift-giving' where humans give pat of themselves. It is only in this respect that we can understand the meaning, importance and significance of sacrifice as rite. Ritual is a language as a language is supposed to be understood against a particular context. Our modern mind shaped by the scientific inquiries and processes that lead to predictable outcomes faces the challenge of some of the traditional world views like rituals where efficacy is considered in terms of symbolism. We can therefore conclude that rituals communicate what individuals consider as beyond, part of the ultimate reality.

\section{PURPOSES OF SACRIFICE}

\section{1. A Gift of Food to the Deity}

This seems to be the underlying reason that most people would attach to sacrifices. Where humanity is conscious of the life obligation in a complex web of relationship, the physical realities are viewed as a blue-print of the invisible world. It is in this case a matter of human perception; the view of the ambivalent existence in nature: where what we see is a replica of what we do not see. In religious language, denial of this truism in consequence does not negate reality. Therefore, as humans relate, their relationship transcends the physical world of the five senses. And if 'man is created in the image of God', it therefore follows that 'man makes God in his own image'. In this relationship, therefore, it follows that whatever happens to us and affects us, also has consequences in the metaphysical world. Just as humans need cordial relationships, the Deity needs such attention as befits from the worshippers. The mystical and magical aspect of sacrifice is encapsulated in the understanding that as an offering, the sacrifice is food to the gods/spirits intended to assuage their anger or a kind of 'grease' to 'soften' the relationship between the gods/spirits and the worshipper. This becomes a kind of the human ability to manipulate the divine and indirectly coerce them to cooperate and do the bidding of the worshipper.

\section{2. Expression of Adoration and Devotion}

Sacrifices as rituals are a means of expression of worship and commitment. Through the shedding of blood of that which is chosen from among the many (consecrated) the worshipper offers that which are of ultimate worth: the life of the victim. It is in this case that the language of sacrifice comes through. The type of the sacrifice is particular, chosen and from among the best, one which is not deformed, undefiled, innocent, tender and highly valued (Lev.1:3, 10; 4:23; Ex.12:15). This implied the pure nature of the sacrifice which was expected to be of the worshipper. This was much more significant in the case of atonement. The understanding here was that the undeserving sinner presented what he was not to take his place, thereby expressing a willingness to be reconciled to harmony with the divine.

The sacrifice in this case became the means by which the worshipper was purified and consecrated. This was the highest point of prayer which expressed love and commitment, evident in the price one had to pay to part with that which was of excellent value.

engagement in the paradigmatic forms and relationship of reality. As such, ritual brings not only the body but also that body's social and cultural identity to the encounter with the transcendental real.' Pp.405-406 


\section{3. Sacrifice among Various Cultures}

The practice of sacrifice pre-dates biblical times. It also goes beyond cultural and time limits. This explains why even in the modern times, sacrifice is still practiced in various ways. We cannot discuss biblical passages without reference to the socio-cultural context in which the people among whom the Bible evolved lived. Our study of the Bible reveals that Israel is a late development in the study of human history. Besides, the nations surrounding the nation of Israel had well developed and highly religious themes and rituals among which were the sacrificial systems. As noted earlier, in the self-understanding of Israel, it set out to become 'different' from other nations by establishing its own identity based on monotheism-the worship of Yahweh. Yahweh was the invisible and ever-present King of the nation. This faith was the foundation stone that was the basis of all relationships-vertical or horizontal. However, this did not mean that the nation was unaware of its history, nor of the cultural heritage of its ancestors. True, through Abraham a new people were coming into existence. But the call of Abraham had to refer to his past: he was called to leave his father's home, land and people, Babylon, the land of many gods (Gen.12:1-9; Jos.24:1-4 to start a new nation whose distinctive mark was monotheism. It important to note that the neighbouring nations like Egypt, Babylon and Canaan had well-developed religions and rituals among which was sacrifice. In most of the cultures of the world then, as it may be in some instances today, sacrifices were considered in magical terms. It was believed that the blood of the sacrifice would turn the face of the deity to look to the good of humanity. Blood in this case is considered to have that mystical 'attraction' effect to the divine:

Then Noah built an altar to the LORD and, taking some of all the clean animals and clean birds, he sacrificed burnt offerings on it. The LORD smelled the pleasing aroma and said in his heart: "Never again will I curse the ground because of man, even though every inclination of his heart is evil from childhood. And never again will I destroy all living creatures, as I have done. Gen.8:20-21 (NIV).

It is evident from this passage that Noah's act contributed to God's covenant with him and the rest of humanity: never to destroy the earth again with water.

\section{4. Sacrifice among the Jews}

In the Jewish sacrificial system, the major reasons and purposes were:

1. Gift: sacrifices were considered as gifts or offerings given to the Deity from whom blessings were expected. Propitiatory sacrifices were performed to induce favour from. The same applied for thanksgiving offerings.

2. Reconciliation: these were sacrifices for reconciliation in matters of sin. These were taken as atonement offerings through which the worshipper would repair the broken relationship with God.

3. Communion: Beyond reconciliation, sacrifices were those that were intended to establish a channel of communication between the worshipper and God.

In all these cases, the victim's life laid down/slain was to represent the highest form of worship through the shedding of blood. Most of the ideas and rites in the Jewish sacrificial system relate to the cultures of the surrounding nations. However, what set apart the Jewish system were the ethical purity and the outlaw of human sacrifice in particular. As noted below, 
when Abraham is tested to offer his only son Isaac, he does not offer him as an offering at the altar since God forbids him (Gen.22). In the case of Jephthah though (Judges 11), he took a vow to sacrifice whatever came out to welcome him if he was to defeat the Ammonites. On his return, he is met first by his only daughter whom he had to do as he had vowed. However, some Bible interpreters do not entertain the possibility of the sacrifice of the girl by Jephthah. They argue that according to the Bible, human sacrifice was clearly a transgression of God's law, and there is no way such an act can be reconciled with the Israelite worship of Yahweh. Others argue that Jephthah, as the text implies in clear terms, sacrificed his daughter as a fulfillment of his vow, and the sacrifice was accepted by God. Yet others claim that good as the rash vow was, and one had to fulfill the vow, human sacrifice was out of question in Israel. According to this view, Jephthah should have confined his daughter to solitary confinement, perpetually making her a virgin. This is in conformity with the Mosaic Law whereby the firstlings of beasts, fruits and people were due to Yahweh (Lev.27:26; Exod.13:12). In case an animal was unclean, it would be redeemed (Lev.27:27). In this case, it has been argued, Jephthah did not ritually kill his daughter.

The argument that to Israel human sacrifices were repugnant could imply that they had been carried out-since legislation is against and existing act or behavior. This implies that there was a time when the practice ceased to be among the people either as a result of religious conviction or legal institution.

The sacrifice of animals derived from the notion of substitution. Since in the blood is life (Gen.9:4), it is the blood that makes atonement for the soul (Lev.17:11). It is Moses who defined the details for sacrifice among the Jews. As Yahweh's prophet, he declared the divine will and set the procedures to be followed and the types of sacrifices worshippers would engage in. however, overall, the guiding principle in worship and sacrifice was the recognition of the holiness of Yahweh, a characteristic that was enjoined of His worshippers too (Lev.11:44). According to the Mosaic legislation, the material of the bloody sacrifice was taken from the personal possession of the worshipper, from among the clean animals (goats, sheep, oxen) as opposed wild game and unclean animals (dogs, pigs, asses, camels). Doves were the only fowls that were sacrificed. Age, sex, and the physical condition of the animals were considered very important: free from defect (Deut.17:1; Lev. 4:23; 9:3; Num.6:14, etc). The act of the sacrifice had a lot of symbolism going with it: presentation of the victim, the placing of hands upon it, slaying, sprinkling the blood, and burning it (Exod.29:42; Lev.1:5; 3:1; 4:6; 4:15; 16:21). The highest point of the ritual was the sprinkling of blood which was exclusively done by the priest alone (Lev.1:5; 3:2; 4:5; 2Chron. 29:23).

\section{5. Sacrifices in Egypt}

Ancient Egypt was extremely polytheistic. A complex variety of gods and goddesses were worshipped in the land. Always understood as personifications of the diverse forces of nature, the gods and goddesses were presented in animal and human forms. The pharaohs were considered both as human rulers and divine beings. Temples abounded in the land attended to by priests of different categories whose duty was to officiate and lead in the worship of the gods. Food and animal sacrifices and offerings were made at the different altars, although we do not have a record of human sacrifices, those who were buried along with the Pharaohs were essentially to help him in the afterlife as it was believed, hence not considered a sacrifice. 


\section{6. Sacrifices in Babylon}

Considered the probable home of Israel's patriarchs, Babylon had a lot of influence on the surrounding nations of the biblical times. It had a well developed culture with all attendant aspects, of which religion was of supreme importance. A reading through, for example, the Babylonian creation accounts ${ }^{6}$ which deal with the people's conception of their history reveals a striking resemblance to that of the Judeo-Christian faith. There was elaborate worship of different divinities in Babylon. Sacrifices of animals and fowls at the temples were common, presided over by priests of the respective cults. Offerings and sacrifices were a source of livelihood for the priests who served at the temples. They (sacrifices and offerings) were in most cases voluntary and an expression of the worship. It was the priests' duty to offer sacrifices on behalf of the worshipper, sometimes retaining portions of the sacrifices for his upkeep. Sacrifices in most cases were therefore part of the ritual observance in worship.

\section{7. Sacrifices in Canaan}

The Canaanite culture was polytheistic. Prominent among the sacrifices were those of children especially to the gods like Chemosh of the Moabites and Molech of the Ammorites. The sacrifice of the first born was considered to be the most efficacious since it was considered the best and dearest to the gods. Being an agricultural land, the religion of ancient Canaan was dominated by a plethora of sacrifices and offerings related to the times and seasons of the year.

\section{8. Sacrifices in Africa}

African culture is a complex web of relationships both on the vertical and horizontal levels. The ontological meaning of humans is viewed as intertwined and based on the hierarchy of supernatural world. In effect, the visible natural world is conceived as a duplicate of the invisible supernatural world. The interrelationship between these spheres of existence is much more a matter of experience, and need no dichotomization. Even without borrowing or being influenced by nether cultural and religious ideas, African life posits a firm belief in the meeting between the two worlds of existence that cannot be objectively identified and analyzed, whose consequences are defined in terms of life and being. Sacrifices in African communities form a very important aspect of religious worship and practice. In this case, sacrifices are considered different from offerings for in sacrifices, the best of the living is what is offered through the shedding of blood. This can be individual or corporate, but in either way is seen as a way of maintaining harmony and peace in the world. It is also considered as a way of showing gratitude, but also in some extreme circumstances, as a way of offering supplications and petitions to the divine. We shall therefore find sacrifices playing an important role in moments of crisis. They come in as the ultimate form of worship-blood signifying life, the best and most valuable the worshipper can offer. In this case, what is offered is a choice gift of an animal, fowl or human being. As noted earlier, this is mostly in times of crises.

\footnotetext{
${ }^{6}$ While the resemblance between the biblical and Babylonian accounts is striking, the biblical one could have evolved as a way of repudiating the existing polytheism of the surrounding nations, coupled with the divinization of nature. What stands out among the Jews is the ethical purity and exclusive monotheism of their belief system.
} 


\section{BIBLICAL VIEW ON HUMAN SACRIFICE}

\section{1. Human Sacrifice in the Old Testament}

Any mention of 'human sacrifice' in Bible evokes Abraham's act (Gen.22) when he was 'told' by God to sacrifice his only and one child, Isaac. Christians consider Abraham to be a hero of faith (Heb.11:17; Jas. 2:21) since he obeyed in spite of the threat to the promise that God had made to him (Gen. 12:2-3; 17:18-19). However, there are problematic issues in the Abrahamic narrative (Gen.22). Does God accept human sacrifices? Does God condone human sacrifice? Did God just want to 'tempt' Abraham-yet He knows the human heart? Through the study of the Old Testament, it is evident that God does not approve of human sacrifice. Human sacrifice was a practice carried out by many nations of the surrounding people (Canaanites, Babylonians, etc). Israel, considering themselves as a people called and set apart by God was not supposed to act in the manner of these nations. Moreover, there is a pointed warning concerning adopting the culture of these nations:

"You must not worship the LORD your God in their way, because in worshiping their gods, they do all kinds of detestable things the LORD hates. They even burn their sons and daughters in the fire as sacrifices to their gods" (Deut.12:31 NIV).

This indictment was clearly to distinguish the people of Israel from others: exclusive and uncompromising monotheism (Exod.23:3; Deut.5:7). Polytheism came with many different religious practices, among which was human sacrifice. From the study of the history of Israel, however, we later find the people adopt the culture of the surrounding nations. They fail to relate with the invisible Yahweh and join in the worship of the fertility cult dominated by Baal at the entry and subsequent settlement in agricultural Canaan (WB Anderson, 1988). While we many times read the Bible as if the contents are arranged in a chronological manner(which should not be the case), the earlier passages are considered to come from after the time of Israel's settlement and are set to explain latter events in the nation. In this case, Israel's disintegration and exile is attributed to their failure to live up to Yahweh's call and purpose. By adopting polytheism, they denied Yahweh, hence their exile (Lev.18:21, 24-30; 2Ki.17:17) 7 . The stark point of the Israelites' syncretism is brought out in 2Kings 16:1-4 when the young king Ahaz made his son to 'pass through the fire' and did all that went with the idolatrous worship of the surrounding nations.

It is argued in biblical scholarship that the passage of Genesis 22 was presented among others in the Bible as an indirect commentary on the polytheistic cult of Israel's neighbours. The passage shows that Yahweh, the God of the Abraham, Isaac and Jacob does not in any way share similarity with the existing pantheons among the Israel's neighbours. Israel is different and set apart. The God of Israel's ancestors, and therefore of their nation, is not given to appeasement and human manipulation through human sacrifice. This is because of the position of humanity in the order of creation-where it is the apex (summit). But this also points to the sanctity of human life as originating from God, and belonging to God alone (Gen.1:27; 9:5-6;

\footnotetext{
${ }^{7}$ Note the reference to pass through the fire to Molech/Molek (v.21) implies human sacrifice. Molech was the sun- god of pleasure worshipped among the Phoenicians. The statues of Molech were big, hollow, bronze statues of a man with an ox's head. Inside, a fire would be kindled and fed until the outstretched arms of it were red-hot. Worshippers of Molech would put their babies on the heated arms, killing them as a sacrifice.
} 
Exod. 21:22-25; Num. 35:33-34). This also explains why the Law was explicit on murder8 (Ex.20:13; Deut.5:17). In the Genesis narrative when Cain kills his brother Abel, the Lord cursed Cain for this act (Gen. 4:10-11). Genesis 9:6 has been identified by some as the basis of capital punishment: "Whoever sheds the blood of man, by man shall his blood be shed; for in the image of God has God made man" (NIV). This underscores the sanctity of human life.

The history of child sacrifice in ancient Israel and God's response to the practice can be uncovered by examining the biblical texts that address it in the Pentateuch, historical books and prophetic writings. In the Pentateuch, Moses warns the Israelites who will soon enter the land of Canaan (Leviticus 18:3 and 20:21-24) where they will be exposed to the cult of Molech not to sacrifice any of their children to the god:

The LORD said to Moses, "Say to the Israelites: "Any Israelite or any foreigner residing in Israel who sacrifices any of his children to Molek is to be put to death. The members of the community are to stone him. I myself will set my face against him and will cut him off from his people; for by sacrificing his children to Molek, he has defiled my sanctuary and profaned my holy name. If the members of the community close their eyes when that man sacrifices one of his children to Molek and if they fail to put him to death, I myself will set my face against him and his family and will cut them off from their people together with all who follow him in prostituting themselves to Molek. (Lev. 20:1-5 NIV)

The penalty for sacrifice to Molech is harsh, i.e., stoning to death (Lev. 20:2); for it is a serious offense against the Lord. This was because such acts defiled God's sanctuary. He is a holy God whose presence cannot abide with sin, among which is child-sacrifice. Besides, childsacrifice to Molech was considered a form of spiritual prostitution. God's relationship with His people is so intimate like in a human marriage covenant. Like one married, there is limited and exclusive commitment that should not know any rivals.

However, it is possible that before Israel's exile, the sacrifice of first-born children became common. These offerings were supposed to fall under the law of firstlings (Jer.7:31; 19:5; Ezek.20:26):

In point of fact, even in old times, when exceptional circumstances called for a human victim, it was a child, and by preference a first-born or only child, that was selected by the peoples in and around Palestine (2Kings 3:27). This is commonly explained as the most costly offering a man can make; but it is rather to be regarded as the choice, for a special purpose, of the most sacred of victim (W.O.E. Oesterley, 1937: 78).

Among the Semitic people, the first-born of both animals and humans were considered sacred (Exod.13:2; 22:29, 30). This is why they occupied first place in the sacrificial victims. However, it is apparent that due to the gruesome nature of human sacrifice, the Israelite religion modified laws pertaining to sacrifice by creating a 'redemption' window (Exod.13:12, 13; 24:20; Num.3:11-13, 40-45) whereby human sacrifices became unacceptable to Yahweh. The evidence available shows that some of the kings of Israel practiced child sacrifice (2Kings $17: 17 ; 21: 6 ; 23: 10)$.

\footnotetext{
${ }^{8}$ This is the deliberate or willful taking of the life of a human being. This excludes war situations. There was a thorough judicial system in Israel that considered details of matters to do with any type of killing/death like in the case of a blasphemer, idolatry, war, etc.
} 


\section{2. Human Sacrifice in the New Testament}

There is no direct reference in the New Testament to human sacrifice. However, it is the once-for-all sacrifice of Jesus Christ in the New Testament that sets it (the New Testament) apart as the fulfillment of the Old Testament. And the sacrifice of Jesus Christ is not supposed to be considered in the way of the worshipper taking of his best from his flock, but in this case, the worshipper is Himself the victim. This is the essence of the writer of the book of Hebrews chapters nine, ten and eleven. Jesus death on the cross is the concern, and in this case, the highest point of the author's argument in presenting a case to us to view the past as the shadows of the present realities. It is the author's argument that whatever happened in the Old Testament was a foreshadow of what was to come in the future: the ultimate end of the sacrifice of Jesus Christ is the forgiveness of sins, and where sins have been forgiven, there remains no more further reasons for sacrifice (Heb.10:18). The type of sacrifice given here is atonement with a permanence stamp since it conforms to God's intended purpose (Heb. 10:7; 9:10), cancelling the repetitive nature of the bloody sacrificial routine.

But the major question is the understanding of the 'atoning sacrifice' or death of Jesus Christ. The argument given is usually that through the fall, humanity had angered God. With the removal of His favour from the fallen humanity, humanity was left lost, helpless and hopeless. No human intervention was capable of salvaging the plight of humanity. What the descendants of Adam awaited was the righteous judgment of God whereby sinners would receive their due: death. The only way out for the world lay in God's grace, mercy and love. However, through divine justice, the anger of God needed satisfaction and the sin of humanity needed atonement:

God is holy; he totally and completely distances himself from sin, evil,
corruption, and the resultant filth and guilt. He maintains his purity and rejects,
fights against, and destroys that which would offend, attack, or undo his
holiness and love. Hence, God's anger and wrath must always be seen in
relation to his maintaining and defending his attributes of love and holiness,
as well as his righteousness and justice. The emotion or passion that moves
God to this maintaining and defending is expressed by the terms "displeasure,"
"indignation," "anger, " and "wrath." A consequence of his wrath is
vengeance, punishment, and death".

Jesus Christ, the Son of God, offered His body (Heb.10:10) and His sacrifice is definitive (Heb.10:11). He is the One who obtained forgiveness through His sacrifice. This is as John would refer to Him: "Behold, the lamb of God, who takes away the sins of the world" (John 1:19).

Christians in the New Testament times must have had times of challenge from their Jewish neighbours who should have questioned their lack of participation in the temple rituals. As the lines of division were clearly being drawn, Christians again should have been confronted by the prevailing Gentile cultures where heroic acts such as 'self-sacrifice' could have been common. However, it is here that the challenge arises. Was Jesus' sacrifice a kind of 'selfsacrifice' (John 10:17-18)? He willingly gives up His life as a ransom for sinners. He pays the debt that is so heavy for humanity to settle. His act is not that of pride (for humanity fell due to this), but rather, a sacrifice for the salvation of many (Mat.20:28; Mark 10:45). Jesus in the New Testament never attacked the sacrificial system. While there exists no record of Jesus

\footnotetext{
${ }^{9} \mathrm{http}: / /$ www.biblestudytools.com/dictionaries/bakers-evangelical-dictionary/wrath-of-god.html Accessed 24th October 2011
} 
Himself participating in the ritual of sacrifice, He can be heard commanding the leper He had healed to perform the ritual just as Moses commanded the Israelites (Mat. 8:4). He (Jesus) never attacks the Jewish sacrificial system (Mat.5:24) and takes it for granted that Jews should carry on with their practice. This is in spite of the fact that we do not see Jesus Himself involved in the sacrificing in the temple, though a frequent worshipper there. He however is set against empty and meaningless ritual devoid of passion and spiritual transformation.

It is at the Last Supper that He identifies His blood as that of the new covenant, poured out for many (Luke 22:20; Mark 14:24; Mat.26:28). His sacrifice does not annul but supersedes all that existed before Him, and none is to come after. This is the tone of the writer of Hebrews in which by His sacrifice, Jesus "obtained eternal redemption" for humanity $(9: 12)$ through a "better covenant" (8:6).

The blood of the New Covenant is the most precious; of a lamb unspotted and undefiled (1Pet.1:18). The bloody sacrifice of the cross as a sin offering occupied the central position in the Pauline preaching. To him, the Redeemer was proposed as the propitiation (Rom.3:25) who saves those who have faith in His blood. The multiplicity and variety of the Mosaic sacrifices showed the inefficacy and inadequacy of the sacrificial system. Jesus Christ's sacrifice was once for all to atone for the sins of many (Heb.9:28; 10:10) as sacrifices were part of worship in the Israelite community, the hallmark of repentance was the sin offering. The pouring out of the blood on the altar was the main part of the sacrifice (Lev.17:11). Atonement in the Old Testament, and consequently in the New Testament is understood only in terms of the blood of sacrifice (Heb.9:11-14):

But when Christ came as high priest of the good things that are now already here, he went through the greater and more perfect tabernacle that is not made with human hands, that is to say, is not a part of this creation. He did not enter by means of the blood of goats and calves; but he entered the Most Holy Place once for all by his own blood, thus obtaining eternal redemption. The blood of goats and bulls and the ashes of a heifer sprinkled on those who are ceremonially unclean sanctify them so that they are outwardly clean. How much more, then, will the blood of Christ, who through the eternal Spirit offered himself unblemished to God, cleanse our consciences from acts that lead to death, so that we may serve the living God!

\section{3. Human Sacrifice in Uganda-the Past and Present}

In Uganda, there exist accounts of human and child-sacrifices from times past. Albert B. Lloyd writing about Uganda by 1921 states:

Human sacrifices were frequent, and birds, beasts, and food were dedicated to the spirits. In Bunyoro it was not uncommon for a child-offering to be made to safeguard a village or tribe. A hole would be dug in the ground in which a child would be buried alive up to its neck and left to die, in order that the spirit might intervene and keep back a threatening enemy or a devastating disease. The idea of sacrifice, ingrained in the human breast, found its outlet in this and other similar practices $^{10}$.

\footnotetext{
${ }^{10} \mathrm{http}$ ///anglicanhistory.org/africa/dayspring.html Accessed 21.9.2012
} 
Human sacrifices were common at times of great challenges:

In Uganda it was customary at the time of national calamity, as when smallpox or plague was devastating the country, for the king himself to go to the witch doctors or heathen priests to find out from them the cause of the trouble. Often at such times a great human sacrifice would be demanded, and at the instigation of the king many would be caught on the public highroads and led off to the place of public execution as human sacrifices. Sometimes the victim was burned to death; on other occasions he was clubbed or thrown into the king's lake, to be devoured by the crocodiles kept there for the purpose. There was no sign of worship, just a ghastly butchery with the hope of propitiating the gods. Let it not be forgotten or overlooked that these acts, fearful and repulsive as they were, were not altogether the outcome of the cruel nature of the Baganda, but of ignorance and helpless fear in face of the great mysteries of life $\mathrm{e}^{11}$.

Granted though that the tone of the script above is reflective of missionary paternalism and bigotry, it however, underscores the reality and scope of human sacrifice in Uganda in the past. It is evident that sacrifices were carried out in times of greet need and challenges such as calamities and serious humans need. There are veiled claims that even in the modern times, where culture demands that certain rituals be performed to the detail, human sacrifices are still carried out especially among communities with traditional rulers/chiefs or kings. Such sacrifices are considered as a means of ensuring the health of the community-they are given as a kind of appeasement, in a way seeking good-will and blessings from the supernatural world. It is in this case that human sacrifice is considered to be the ultimate way of worship-human blood being very valuable (efficacious) and favourable to signify the level of commitment on the part of the worshipper. However, it is important to note that human sacrifice in the past was not carried out by individuals to meet their religious obligations, but rather whole communitiesimplying the magnitude of the need. However, to date, with the invasion of the capitalist economy that places individual needs above those of the community, with grand projects and investments to be undertaken, some people could 'represent' whole communities and feel the need to carry the weight that would have been borne by many, thereby practicing human sacrifice.

This may partly explain the resurgence of human sacrifices in Uganda today. Reports exist in the media ${ }^{12}$ that allude to the practice being practiced especially by people involved in especially commercial deals and the construction industry. The author has seen sacrifices of chicken being carried out on small scale undertakings like when a new vehicle has been bought, the laying of the foundation for a new house, the roofing of houses, and brick-baking (burning). It therefore would look like the sacrifice hypothesis would stand as "the greater the project, the bigger the sacrifice". This would fit in well with the Christian understanding of Jesus Christ's death-He became the atoning sacrifice for humanity, and the entire world such that whoever would partake of His price as paid through His death, would by grace appropriate the finished work through faith.

\footnotetext{
${ }^{11}$ Ibid.

${ }^{12}$ The challenge of most media reports in Uganda is that they sometimes carry sensational messages. Many times it has been found that media practitioners lack investigative capabilities. However, like never before, human sacrifice has been reported by especially the print media. It has been argued by some that it is not that the magnitude of the act has increased, but rather that media coverage has publicized the ritual.
} 


\section{4. Why Now?}

One would wonder why human sacrifices would be carried out in Uganda today after years by penetration of Islam and Christianity. Such denials would be easily countered by the fact that there are many aspects of African life that were not dealt away with by the two religious institutions. While some of the reasons as to why this came to be can be found in the internal weaknesses of the respective religious traditions themselves, others have much more to do with identity. It is under the identity aspect that Islam and Christianity have been viewed as competing worldviews with African Indigenous beliefs and practices. While the two-Islam and Christianity came as agents of 'civilization', indigenous worldviews presented immediate answers and solutions to the seekers. Islam and Christianity came couched in Arabic and European cultures where slave trade was dominant along with the colonization and subjugation of the African people. This strengthened the position of some indigenous leaders to present the case of the relevance of their age-long philosophy and ideology. Even where internal reforms were carried out in the respected new religious institutions, these were not radical enough to address the great divide that had been created by the first preachers and teachers of these religions.

It is amazing to see the power and influence of indigenous beliefs through the practices of most African 'converts' to Islam and Christianity. Overtime we have seen the apparent 'marriage of convenience' between the three religious traditions. There are many situations where certain degrees of 'innovation', 'creativity', 'cooperation', 'enculturation', 'indigenization' have produced certain forms of either Islam or Christianity 'made in Uganda'. There are also instances where for example the Church has given way to African 'tradition' and 'culture' to have its way, and come in only as a 'seal' or 'climax' of certain beliefs and practices. For example, most traditional and cultural leaders in Uganda subscribe to the Christian faith. During some of the ceremonies, Church leaders have given license to traditional ritual leaders to perform their rituals first and then come in with the 'Church' (Christian) ones later.

To a keen observer, the rituals performed seem to complement each other and reinforce the participants' beliefs. This has greatly contributed to syncretism, a reality which is evident among most believers today. With such recognition by both Islam and Christianity of certain ceremonies dubbed 'traditional' and 'cultural', coupled with the national constitutional ${ }^{13}$ framework, it becomes difficult to work towards the radical conversion of those who consider 'all religions equal' in Uganda. To most believers, they see no contradiction between their culture, tradition and Christianity.

In some regions of the country, the story of the spread of especially missionary Christianity is a complex one. It is apparent that 'conversions' in such cases were thought in terms of 'civilization' and 'modernization'.

The 'new religion' was seen as a means of 'adjusting' to the realities of the time, a method of 'coping' especially given the fact that this was the religion of the strong and mighty colonialist who had the power of modern warfare. It was therefore considered for better to make peace with the strong adversary in the hope that with time, the 'invaders' would lose out to the strong ties that bound the people together.

\footnotetext{
13 The Ugandan Constitution-Article 7 states: Uganda shall not adopt a State religion; while 29(c) states the right to "freedom to practice any religion and manifest such practice which shall include the right to belong to and participate in the practices of any religious body or organization in a manner consistent with this Constitution". Article 37 is very much pronounced on culture: "Every person has a right as applicable, to belong to, enjoy, practice, profess, maintain and promote any culture, cultural institution, language, tradition, creed or religion in community with others".
} 
It is in this case that there was no call for a radical break with the existing beliefs and practices. Christianity became a sort of veneers, a superimposed thin layer that people had to attend to in order to be en vogue. This is what has given rise to popular Christianity, a type that meets the convenience of those who desire certain requirements to be met at any cost, especially where the need is 'realistic' and fitting in the world of the believer. However, the current debate would go a notch higher especially in the context of human growth and development.

The area of killing and murder is dominated by ethical landmines which every pilgrim has to be aware of. While debates in Uganda rage on concerning capital punishment-whether it should be abolished or not, some will bring into the debate matters of human sexuality, family planning and birth-control. The issue of abortion would rank highest in this debate: how it should be viewed in its essential nature.

There is a view coming from some, especially Christians that all manner of birth-control and family planning methods are abortion in nature, while some hold some of the methods like those that interfere with the fertilized ovum, thereby denying it growth as 'murder' ${ }^{14}$. To these, any intentional expulsion of a fertilized ovum under whatever circumstances is considered 'murder'.

This is viewed as a kind of 'sacrifice' for the good of others. By extension, in these quarters, child-sacrifice becomes associated with abortion. It is in this that African culture reinforces Christian beliefs in our context to determine perspectives.

\section{CONCLUSIONS}

There is the view that the purpose or motive for sacrifice is much more significant than the act itself. If this is so, then it would follow that there is no essential difference between animal sacrifice and human sacrifice, and in many cases one is substituted for the other ${ }^{15}$. This seems to be the underlying belief today as some people seek the blessings of the divine in light of material human development and prosperity, whereby even the Christian Church as adopted miracles, signs and wonders as the share of those who believe in Jesus Christ. However, for one to be a partaker of these 'blessings', there is a sacrifice to be borne. This could be in terms of giving an offering beyond the 'normal' so as to attract a blessing of bounty and prosperity.

Amidst such beliefs, there are many other teachings from competing ideologies that are bound to emerge to counter the 'foreign' ones ${ }^{16}$. Some people have chosen to be innovative and adapted traditional cults to the new situations. While some of such innovations may adopt an amalgam outlook, others retain their distinct traditional outlook. This is true in areas of ritual and religion, beliefs and practices. We note that rituals address situations of tension, strain and anxiety. Given the rapid social changes sweeping of the world, there are creative ways of maintaining equilibrium in all ways of life, sacrifice being one of them.

\footnotetext{
${ }^{14}$ In some of the Ugandan cultures, where a couple has few children through family planning procedures, some elders consider such couples as having 'killed' the children while still in the womb.

${ }^{15}$ Girard, op.cit. p.10

16 There are modern day 'wedding ceremonies' and 'end of year celebrations' performed in traditional worship styles. Some of the traditional religious practices and procedures have been 'modernized' to appeal to the elite.
} 


\section{References}

[1] Catholic Encyclopedia-http://www.newadvent.org/cathen/13309a.htm

[2] Rosalie D., Handbook to Life in Ancient Egypt: Facts on File; New York, 1998.

[3] Beattie J., Other Cultures: London, Routledge and Kegan Paul, 1964.

[4] Girard R., Violence and the Sacred: (Translated by Patrick Gregory), London: The John Hopkins University Press, 1977.

[5] The Uganda Constitution, Government of Uganda. Ministry of Justice and Constitutional Affairs, 1995.

[6] Anderson W.B., The Living Word of the Old Testament (Fourth Edition): England; Longman, 1988.

[7] Lambert W. C. and Parker S. B., Enûma Eliš: The Babylonian Epic of Creation, Oxford, 1966.

[8] Oesterley W.O.E., Sacrifices in Ancient Israel: Their Origin, Purpose and Development, London, Hodder and Stoughton, 1937.

[9] http://www.biblestudytools.com/dictionaries/bakers-evangelical-dictionary/wrath-ofgod.html Accessed 24th October 2011. 